Please do not remove this page

RMIT

UNIVERSITY

\title{
A new species of Prosorhynchoides (Trematoda, Bucephalidae) from the intertidal rocky zone of central Chile
}

Munoz, Gabriela; Bott, Nathan

https://researchrepository.rmit.edu.au/esploro/outputs/9921859799901341/filesAndLinks?institution=61RMIT_INST\&index=null

Munoz, G., \& Bott, N. (2011). A new species of Prosorhynchoides (Trematoda, Bucephalidae) from the intertidal rocky zone of central Chile. Acta Parasitologica, 56(2), 140-146.

https://doi.org/10.2478/s11686-011-0017-y

Document Version: Published Version

Published Version: https://doi.org/10.2478/s11686-011-0017-y

Repository homepage: https://researchrepository.rmit.edu.au

(C) 2011 Versita Warsaw; (c) W. Stefanski Institute of Parasitology, PAS

Downloaded On 2023/04/26 22:01:00 +1000 
Thank you for downloading this document from the RMIT Research Repository.

The RMIT Research Repository is an open access database showcasing the research outputs of RMIT University researchers.

RMIT Research Repository: http://researchbank.rmit.edu.au/

\section{Citation:}

Munoz, G and Bott, N 2011, 'A new species of Prosorhynchoides (Trematoda, Bucephalidae) from the intertidal rocky zone of central Chile', Acta Parasitologica, vol. 56, no. 2, pp. 140-146.

See this record in the RMIT Research Repository at:

https://researchbank.rmit.edu.au/view/rmit:26168

Version: Published Version

Copyright Statement: (c) 2011 Versita Warsaw ; @ W. Stefanski Institute of Parasitology, PAS

Link to Published Version:

http://dx.doi.org/10.2478/s11686-011-0017-y 
This work is licensed under the

Creative Commons Attribution-NonCommercial-NoDerivatives 3.0 License.

For the terms of the license, please go to:

http://creativecommons.org/licenses/by-nc-nd/3.0/ 


\title{
A new species of Prosorhynchoides (Trematoda, Bucephalidae) from the intertidal rocky zone of central Chile
}

\author{
Gabriela Muñoz ${ }^{*}$ and Nathan J. Bott ${ }^{2}$ \\ ${ }^{1}$ Facultad de Ciencias del Mar y de Recursos Naturales, Universidad de Valparaíso, Casilla 5080, Valparaíso, Chile; \\ ${ }^{2}$ Aquatic Sciences, South Australian Research and Development Institute, PO Box 120, Henley Beach, SA 5022, Australia
}

\begin{abstract}
A new bucephalid species, Prosorhynchoides carvajali sp. nov. is described. This parasite was found in three marine fish, Auchenionchus microcirrhis (type-host), A. variolosus and Sicyases sanguineus (other-hosts), collected from the intertidal rocky zones of central Chile. P. carvajali sp. nov. is characterized by a pharynx in a post-equatorial position, a large cirrus sac length (half of the total worm length) and rounded caecum extending dorsally and anteriorly from pharynx. Although Prosorhynchoides carvajali sp. nov. closely resembles $P$. labiata; the latter has an elongated, narrow and inverted-U-shape caecum, contrasting to $P$. carvajali sp. nov. which has a larger rounded caecum, directed anteriorly. To our knowledge this is the first known report of Prosorhynchoides on the South American Pacific coast.
\end{abstract}

\section{Keywords}

Digenea, Bucephalidae, Prosorhynchoides, taxonomy, Chile

\section{Introduction}

The Bucephalidae Poche, 1907 is one of the largest families of digeneans, currently containing 25 genera and hundreds of species. They are cosmopolitan and are found in marine, brackish and freshwater fishes (Overstreet and Curran 2002). In spite of their widespread distribution, little is known of the host allocation from numerous localities. For example, 32 species have been recorded in fishes from South America, including marine and freshwater systems according to the checklist of trematodes for this area provided by Kohn et al. (2007); 20 species in Brazil, five in Argentina, five in Ecuador, two in Venezuela, two in Colombia, and one in Chile.

Specifically for Chile, there is a paucity of biological and taxonomic studies about the bucephalid fauna of fishes. The only bucephalid identified to species is Bucephalus gorgon (Linton, 1905), previously reported as B. introversus Manter, 1940, in Seriola lalandi by Luque and Oliva (1993). Unidentified species have been found in fish and bivalves: adults for Prosorhynchus sp. in Paralichthys adspersus and Merluccius gayi gayi (according to Oliva and Ballón 2002, Oliva et al. 1996, respectively); unknown species in Cilus gilberti and Nezumia pulchella (Garcías et al. 2001, Salinas et al. 2008, respectively); and larval stages in mytilid bivalves, $P e-$ rumytilus purpuratus and Semimytilus algosus (Lasiak 1991).
During a study of parasite community of teleosts from the intertidal rocky zone of central Chile, bucephalid digeneans were found in the intestinal tract of some labrisomid and gobiesocid fish, which do not have records of these parasites (Muñoz and Olmos 2008). These fish are sympatric species, although with different biological characteristics; labrisomids are normally found in intertidal rocky pools. They are carnivorous and reach up to $22 \mathrm{~cm}$ in length (Muñoz and Ojeda 1998). Gobiesocid fish are found in fissures and attached to rocks, by a ventral sucker, exposed to waves. They are omnivorous and reach up to $35 \mathrm{~cm}$ in length when adults (Muñoz and Zamora 2011).

The bucephalids found in labrisomid and gobiesocid fish conform to the diagnosis of Prosorhynchoides Dollfus, 1929 provided by Overstreet and Curran (2002), although with some morphological differences in comparison to other described species. Therefore, this study aims to describe a new species of Prosorhynchoides.

\section{Materials and methods}

The fishes Auchenionchus microcirrhis, A. variolosus and Sicyases sanguineus were collected between 2006 and 2008, from the central coast of Chile $\left(33^{\circ} \mathrm{S}\right)$. The fishes were dissected and the digestive tract was removed and examined 
under a stereo microscope. Bucephalids were mostly observed in the posterior part of the intestine and the rectum. Some specimens were fixed in $10 \%$ formalin prepared in a physiological solution for staining procedures and others were fixed in $100 \%$ ethanol for molecular analysis.

The bucephalids were stained with hematoxylin, dehydrated in alcohol from $70 \%$ to $100 \%$, cleared in methyl salicylate and mounted in Canada balsam. Measurements were performed with an eye-piece micrometer, and drawings were made with "camera lucida", both attached to a Leica DM LS2 light microscope. The prevalence and mean intensity of bucephalids was calculated according to Bush et al. (1997). All ranges of measurements, followed by the mean in parentheses, are expressed in micrometers $(\mu \mathrm{m})$. Morphological comparisons were made against 81 Prosorhynchoides species, including those transferred to this genus after their original description.

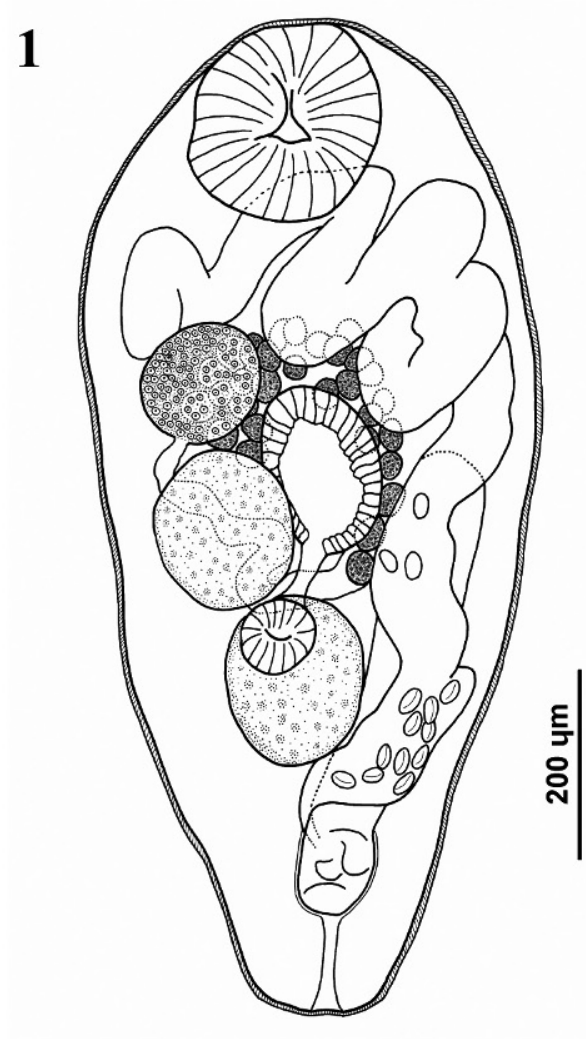

2

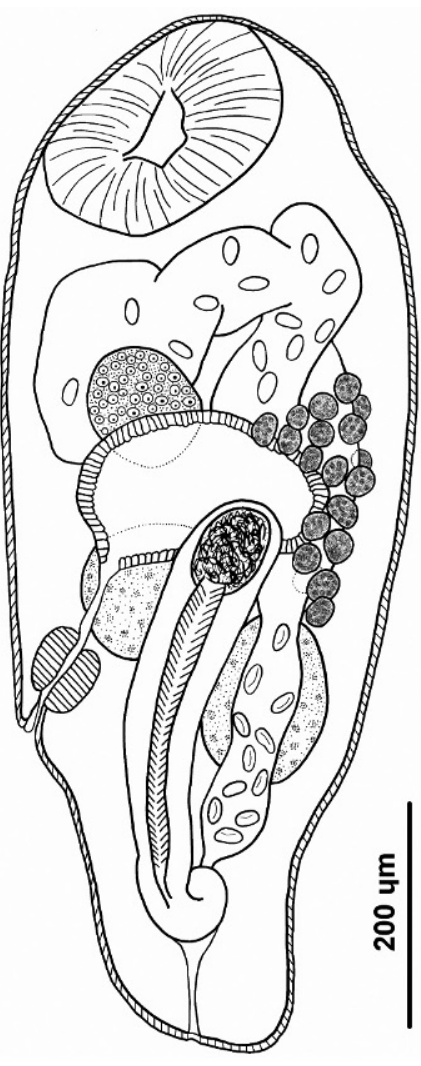

\section{3}

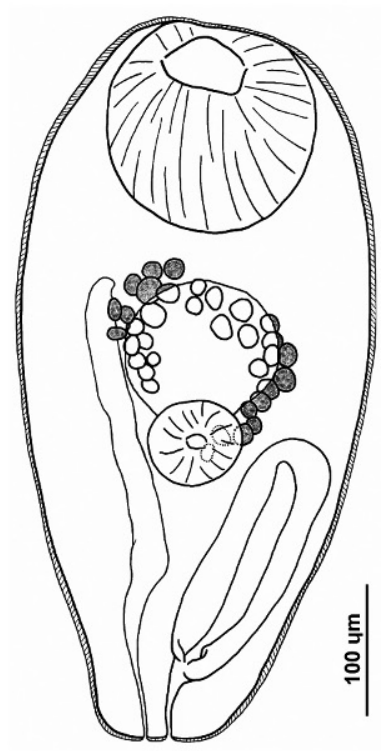

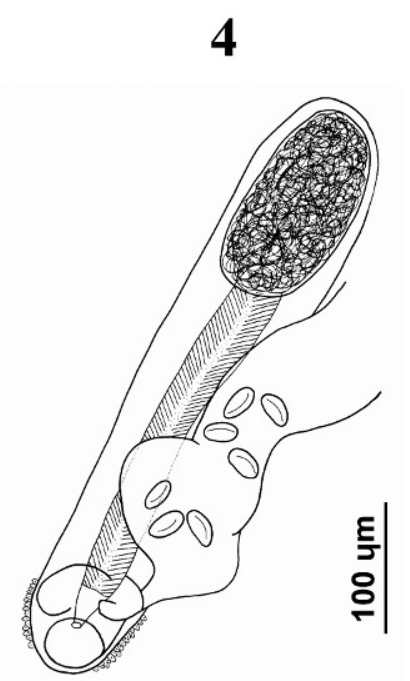

5

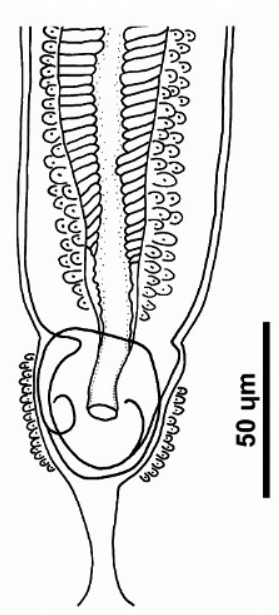

6

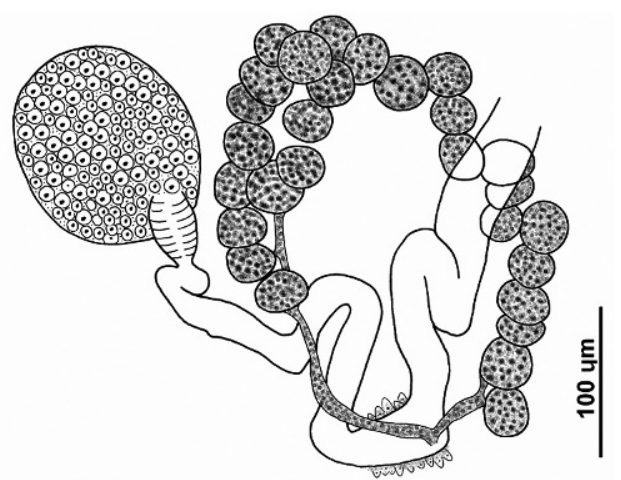

Figs 1-6. Prosorhynchoides carvajali sp. nov. 1. Ventral view (holotype). 2. Lateral view (paratype). 3. Ventral view of a juvenile. 4. Cirrus sac. 5. Details of the posterior portion of cirrus sac. 6. Female reproductive system 
To extract genomic DNA from ethanol fixed worms, found in the three fish species the phenol-chloroform method of Sambrook et al. (1989) was used. The V4 region of the SSU rRNA (18S) gene was amplified using the primers SB3a and A27a, following the protocol described by Hall et al. (1999).

Each polymerase chain reaction (PCR) had a final volume of $25 \mu$ l, using $0.125 \mu \mathrm{L}$ de Taq (5U/ $\mu \mathrm{L}), 2.5 \mu \mathrm{L}$ Buffer (10X), $2 \mu \mathrm{L}$ dNTPs $(2.5 \mathrm{mM}), 4 \mu \mathrm{L} \mathrm{MgCl}_{2}(25 \mathrm{mM}), 0.5 \mu \mathrm{L}$ of each primer (Sb3a and A27a), $3 \mu \mathrm{L}$ template DNA and adding $12,375 \mu \mathrm{L} \mathrm{H}_{2} \mathrm{O}$ to complete the final volume. A Perkin Elmer Thermal Cycler (Massachusetts, USA) was used with a cycling profile as follows: initial denaturation step at $95^{\circ} \mathrm{C}(5$ min) followed by 35 cycles at $94^{\circ} \mathrm{C}(30 \mathrm{~s}), 45^{\circ} \mathrm{C}(30 \mathrm{~s}), 72^{\circ} \mathrm{C}$ ( $3 \mathrm{~min}$ ), and a final extension step at $72^{\circ} \mathrm{C}(10 \mathrm{~min})$. Doublestranded PCR products were observed in $1.5 \%$ agarose gel slides. Then, the products were cleaned using an E.Z.N.A TM Cycle-Pure Kit (Omega Bio-Tek, Inc., Atlanta, Georgia, USA) and both DNA strands were directly sequenced (Macrogen, Seoul, Korea; http://www.macrogen.com). Sequences were edited using ProSeq v 2.9 beta (Filatov 2002) and aligned with Clustal X (Larkin et al. 2007).

\section{Results}

The molecular analysis showed that the nucleotide composition of the worms from the three fish hosts were identical (Table I); no base pair differences between the sequences of samples of A. microcirrhis (two replicates), A. variolosus (one replicate) and $S$. sanguineus (three replicates) were found.

Bucephalidae Poche, 1907

Bucephalinae Poche, 1907

Prosorhynchoides Dollfus, 1929

Prosorhynchoides carvajali sp. nov. (Figs 1-6, Table II)

Description (based on 17 wholemounts of adult specimens): Body small, ellipsoid, 453-1100 (927) long, 275-550 (422) wide at widest part, with anterior half wider than posterior half. Tegument entirely covered by small spines, 5-6 long. Rhynchus a simple muscular sucker, 113-225 (186) long, 125-250 (205) wide. Mouth opening ventrally, post-equatorial and directed posteriorly, 138-400 (297) from posterior end, corresponding to $27.9-39.3 \%$ (32.1\%) of body length (Figs 1, 2). Pharynx 48-100 (72) long, 50-106 (77) wide. Caecum rounded, saccular, extending dorsally and anteriorly from pharynx, 130-263 (182) long, 125-204 (153) wide (from frontal view, Fig. 1), with walls of large cells 15-50 (26) long. Excretory vesicle I-shape, slender, reaching level between anterior part of caecum and rhynchus, observed clearly in juveniles (Fig. 3). Excretory pore terminal, close to genital pore. Common genital pore of genital atrium posteriorly terminal. Genital duct 31-100 (73) (Fig. 4). 
Testes 2, entire, subspherical, dextral, anterior slightly oblique to posterior, sometimes overlapping by short distance 0-75 (36); anterior testis 88-206 (154) long, 69-213 (141) wide; posterior testis 91-206 (150) long, 71-1181 (136) wide; anterior testis more ventral than posterior. Cirrus sac sinistral, extending to level of ovary, 260-525 (421) long, 53-100 (80) wide, widest near middle. Seminal vesicle ellipsoid, 67 218 (126) long, 44-113 (72) wide. Pars prostatica bending slightly, 145-369 (275) long, filling cirrus sac between seminal vesicle and posterior end. Ejaculatory duct narrow, short. Genital atrium ovoid containing three rounded protuberances. Genital atrium ovoid, 40-100 (71) long, 43-115 (75) wide (Figs 4, 5).

Ovary oval, pretesticular, dextral, with posterior margin ventral to anterior testis, 53-150 (115) long, 53-138 (100) wide. Oviduct descending from ventro-lateral side of ovary. Mehlis' gland posterior to ovary, at level of anterior testis (Fig. 6). Laurer's canal not observed. Vitellarium consisting of 28 35 follicles, arranged in 2 lateral asymmetrical fields at level of caecum (Figs 3, 6), extending between ovary and anterior testis (Fig. 1); dextral field 75-300 (178) long; sinistral field 100-425 (212) long. Uterine loops occupying entire space anterior to pharynx. Eggs numerous, tanned, oval 25-29 (27) long, 13-18 (15) wide (eggs measured from distal portion of uterus only).

Type-host: Auchenionchus microcirrhis (Valenciennes, 1836) (Labrisomidae).

Other hosts: Auchenionchus variolosus (Valenciennes, 1836) (Labrisomidae), Sicyases sanguineus (Müller et Troschel, 1843) (Gobiesocidae).

Site of infection: Posterior portion of the intestine, mainly in the rectum.

Type-locality: El Tabo $\left(33^{\circ} 27^{\prime} \mathrm{S}, 71^{\circ} 37^{\prime} \mathrm{W}\right)$, central Chile.

Other localities: Las Cruces ( $\left.33^{\circ} 30^{\prime} \mathrm{S}, 71^{\circ} 38^{\prime} \mathrm{W}\right)$, Montemar $\left(32^{\circ} 58^{\prime} \mathrm{S}, 71^{\circ} 29^{\prime} \mathrm{W}\right)$, central Chile.

Prevalence and intensity of infection: 18 Auchenionchus microcirrhis from El Tabo were parasitized (23.97\% of 78),
8.05 mean intensity (range 1-44); 6 A. microcirrhis from Las Cruces were parasitized (9.52\% of 63), 12.16 mean intensity (range 1-36); 2 A. variolosus parasitized from El Tabo (28.5\% of 7), 20.1 mean intensity (range 3-137); 6 Sicyases sanguineus were parasitized from Montemar (28.6\% of 21); 3.83 mean intensity (range 1-8).

Deposition of specimens: Museo de Zoología, Universidad de Concepción, Chile, MZUC: 29823 (holotype), 29824 29825 (paratypes).

Etymology: The specific name refers to Professor Juan Carvajal, in recognition of his distinguished contribution to the marine parasitology of Chile.

\section{Remarks}

Relative to all previously described species of Prosorhynchoides, $P$. carvajali sp. nov. resembles 12 species (Table III) in the following features, small ratio of body length:wide (2-3:1), most with short body length $(<1.5 \mathrm{~mm})$, except $P$. rioplatensis (Szidat, 1970) and P. belonea (Srivastava, 1938) that reach near $2.5 \mathrm{~mm}$ as maximum length; and relative long cirrus sac, occupying at least half the total body length (Table III). However, P. carvajali sp. nov. differs from most of these species in that the mouth is post-equatorial, and the vitelline follicle distribution is approximately at the equator (slightly anterior). In these characters, $P$. carvajali sp. nov. is resembles P. karvei (Bhalerao, 1937), P. belonea, P. gauhatiensis (Gupta, 1953) and P. labiata (Manter and Van Cleave, 1951). However, $P$. carvajali sp. nov. has the vitelline follicles distributed near the equator of the body in the dorsal plane (Fig. 2), which contrasts to $P$. gauhatiensis, $P$. belonea and $P$. karvei which have the vitelline follicles in the anterior portion of the body, close to the rhynchus. Only P. labiata has the vitelline follicles distribution similar to that of $P$. carvajali sp. nov. However, these two species differ significantly in caecum shape. The caecum of P. labiata has an inverted$\mathrm{U}$ shape so that oesophagus and part of the caecum is di-

Table II. Morphometrical comparison between P. labiata Manter et Van Cleave, 1951 and P. carvajali sp. nov. from different fish

\begin{tabular}{|c|c|c|c|c|}
\hline & $\begin{array}{c}\text { P. labiata } \\
\text { (Manter et Van Cleave } \\
\text { 1951) }\end{array}$ & & $\begin{array}{l}\text { P. carvajali sp. nov. } \\
\text { this study }\end{array}$ & \\
\hline $\begin{array}{l}\text { Fish host } \\
\text { Morphometric }\end{array}$ & $\begin{array}{l}\text { Paralichthys } \\
\text { californicus } \\
\mathrm{n}=9\end{array}$ & $\begin{array}{c}\text { Auchenionchus } \\
\text { microcirrhis } \\
\mathrm{n}=17\end{array}$ & $\begin{array}{c}\text { Auchenionchus } \\
\text { variolosus } \\
\mathrm{n}=5\end{array}$ & $\begin{array}{c}\text { Syciases } \\
\text { sanguineus } \\
\mathrm{n}=3\end{array}$ \\
\hline Body length $\times$ width & $635-745 \times 234-328$ & $453-1100 \times 275-550$ & $750-910 \times 360-450$ & $775-813$ \\
\hline Rhynchus width & $127-146$ & $125-250$ & $150-233$ & $200-220$ \\
\hline Pharynx width & $71-80$ & $50-106$ & $81-98$ & $80-91$ \\
\hline Caecum (length $\times$ width) & $188 \times 29 *$ & $130-263 \times 125-204$ & $88-125 \times 100-119$ & $110-150 \times 111-137$ \\
\hline Cirrus sac (length $\times$ width) & $314-360 \times 66-73$ & $260-525 \times 53-100$ & $338-400 \times 54-75$ & $382-371 \times 65-81$ \\
\hline $\begin{array}{l}\text { Seminal vesicle } \\
\quad(\text { length } \times \text { width })\end{array}$ & $76-78 \times 46-70$ & $67-218 \times 44-113$ & $87-112 \times 37-81$ & $75-88 \times 69-75$ \\
\hline Eggs (length $\times$ width) & $25-31 \times 16-17$ & $25-29 \times 13-18$ & $24-31 \times 14-19$ & $23-27 \times 13-16$ \\
\hline
\end{tabular}

*Measurement obtained from a drawing in Manter and Van Cleave (1951). 


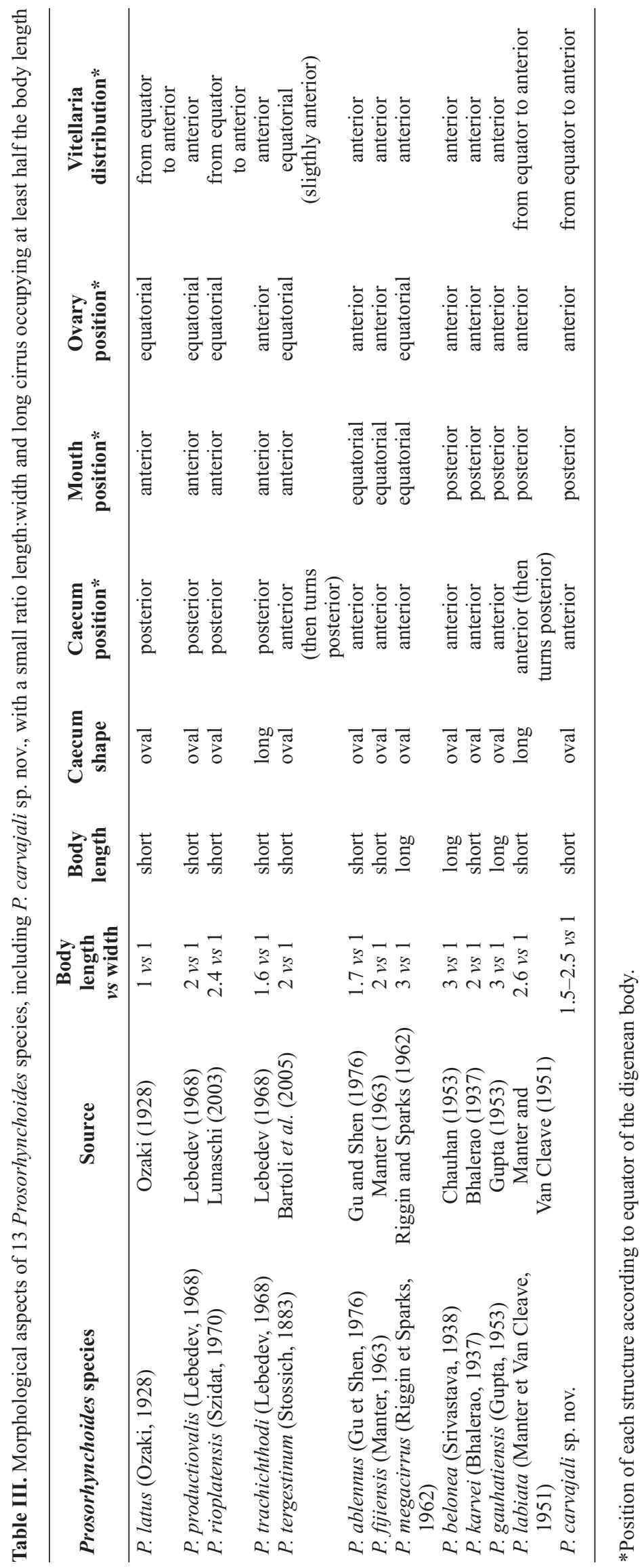


rected anteriorly and then curves posteriorly, terminating slightly anterior to the level of the mouth (Manter and Van Cleave 1951). The caecum necessarily has to be long and slender to have this shape, comparably slender caeca have been reported in other species (e.g. P. tenius in Yamaguti 1952), P. mehrai in Agarwal and Agarwal (1986); P. lamprelli in Bott and Cribb (2005). Unfortunately, the description of $P$. labiata did not mention the size range of the caecum or show it completely in drawings (Manter and Van Cleave 1951). In addition, the caecum of this species was not easily visible in the holotype (from pictures provided by the U.S. National Parasite Collection). However, according to the drawing and description provided in the original description, the caecum measures approximately $188 \mu \mathrm{m}$ long and $29 \mu \mathrm{m}$ wide, which contrasts with the large rounded caecum of $P$. carvajali sp. nov. (Table II). In the new species the thick-walled anteriorly directed caecum, is easily distinguishable in all of the specimens observed, from juveniles to adults (Figs 1-3).

Other differences between P. labiata and P. carvajali sp. nov. are in the morphometric ranges for several features, such as size of body, rhynchus, pharynx and cirrus sac. There is some morphometric overlap between these species, but $P$. carvajali sp. nov. is larger in overall size and other structures in comparison to P. labiata (Table II).

Prosorhynchoides carvajali sp. nov. from A. variolosus and $S$. sanguineus were slightly larger than those from $P$. labiata, but slightly smaller than those found in A. microcirrhis (Table I). Molecular analyses of $P$. carvajali from the three fish species, confirms that they are the same species (Table I). Most specimens of $P$. carvajali sp. nov. from $A$. variolosus and $S$. sanguineus were immature and not fully developed, contrasting with $P$. carvajali sp. nov. collected from A. microcirrhis, which was less abundant, but were mostly mature.

Manter and Van Cleave (1951) reported a small lip anterior to the pharynx in P. labiata that has not been observed in other species. This lip was observed in some specimens of $P$. carvajali sp. nov. (Fig. 2), although it seems to be an evagination of the internal wall of the mouth, we do not consider it a consistent structure to distinguish species.

There are also biological differences between P. labiata and $P$. carvajali sp. nov., in host species and locality. P. labiata is a parasite from the flatfish Paralichthys californicus from the coast of California, USA. In contrast, P. carvajali sp. nov. is present in intertidal fish (mainly in Auchenionchus spp.) from the coast of central Chile. Because these two localities are from different hemispheres, with a huge distance between them, the migrations of host species harbouring this parasite between the two locations seems implausible. In addition, there is only one report of a Prosorhynchides $\mathrm{sp}$. in a labrisomid fish, Labrisomus philippi in the Peruvian coast (Oliva and Luque 2002), and none in gobiesocids. Although L. philippi is found in Chile, this has no record of bucephalid trematodes (Muñoz and Olmos 2008). Consequently, there is morphological, morphometri- cal and biological evidence to propose to $P$. carvajali sp. nov. as a new species.

Acknowledgements. We thank the U.S. National Parasite Collection for facilitating pictures of the P. labiata holotype that allowed us to make morphological comparisons and descriptions. Ms. M. Isabel Valdivia, Universidad de Antofagasta, for her assistance with molecular analyses. This study was partially supported by FONDECYT 11060006 and DIPUV 12/2008 awarded to GM; NJB was supported by Marine Innovation South Australia, an initiative of the South Australian Government.

\section{References}

Agarwal R.K., Agarwal S.M. 1986. Studies on family Bucephalidae Poche, 1907. Revista di Parassitologia, 3, 53-58.

Bartoli P., Bray R.A., Gibson D.I. 2005. Three poorly known and rarely reported bucephalid species (Digenea) in fishes from the Western Mediterranean. Systematic Parasitology, 62, 135 149. DOI 10.1007/s11230-005-5489-4.

Bhalerao G.D. 1937. Studies on the helminths of India. Trematoda IV. Journal of Helminthology, 15, 97-124. DOI: 10.1017/S0022 149 X00030753.

Bott N.J., Cribb T.H. 2005. Prosorhynchoides lamprelli n. sp. (Digenea: Bucephalidae) from the brassy trevally, Caranx papuensis (Teleostei: Carangidae), from off Lizard Island on the Great Barrier Reef, Australia. Zootaxa, 1059, 33-38. DOI: DO00001374.

Bush A.O., Lafferty K.D., Lotz J.M., Shostak A.W. 1997. Parasitology meets ecology on its own terms: Margolis et al. revisited. Journal of Parasitology, 83, 575-583. DOI: 10.2307/3284227.

Chauhan B.S. 1953. Studies on the trematode fauna of India. Part III. Subclass Digenea (Gasterostomata). Records of the Indian Museum, 51, 231-287.

Filatov D.A. 2002. Proseq: a software for preparation and evolutionary analysis of DNA sequence data sets. Molecular Ecology Notes, 2, 621-624.

Garcías F., Mendoza R., George-Nascimento M. 2001. Variación entre anos de las infracomunidades de parasitos metazoos de la corvina Cilus gilberti (Pisces: Sciaenidae) en Chile. Revista Chilena de Historia Natural, 74, 833-840. DOI: 10.4067/ S0716-078X2001000400010.

Gu C.D., Shen J.W. 1976. Report on some gasterostomatous trematodes (Family Bucephalidae Poche, 1907) from marine fishes in Dong Hai and Nan Hai, China. Acta Zoologica Sinica, 22, 371-384 (In Chinese).

Gupta S.P. 1953.Trematode parasites of fresh-water fishes. Indian Journal of Helminthology, 5, 1-80.

Hall K.A., Cribb T.H., Barker S.C. 1999. V4 region of small subunit rDNA indicates polyphyly of the Fellodistomidae (Digenea) which is supported by morphology and life-cycle data. Systematic Parasitology, 43, 81-92. DOI: 10.1023/A:1006113 721899.

Kohn A., Fernandes B.M.M., Cohen S.C. 2007. South American trematodes parasites of fishes. Imprinta Express Ltda., Rio de Janeiro, 318 pp.

Larkin M.A., Blackshields G., Brown N.P., Chenna R., McGettigan P.A., McWilliam H., Valentin F., Wallace I.M., Wilm Lopez R., Thompson J.D., Gibson T.J., Higgins D.G. 2007. Clustal W and Clustal X version 2.0. Bioinformatics, 23, 2947-2948. DOI: 10.1093/bioinformatics/btm404.

Lasiak T. 1991. Bucephalid trematode infections in mytilid bivalves from the rocky intertidal of southern Chile. Journal of Molluscan Studies, 58, 29-36. 
Lebedev B.I. 1968. Trematodes of the family Bucephalidae from commercially important marine fish of New Zealand and Australia. In: Parasites of animals and plants (pp. 156-167). Izd. Nauka, Moscow (In Russian).

Lunaschi L. 2003. Prosorhynchoides rioplatensis (Szidat, 1970) comb. nov. (Digenea, Bucephalidae) from Catathyridium jenynsii (Günther, 1862) (Pleuronectiformes, Achiridae) in Argentina. Acta Parasitologica, 48, 83-86.

Luque J.L., Oliva M. 1993. Trematodes of marine fishes from the Peruvian Faunistic Province (Peru and Chile), with description of Lecithochirium callaoensis n. sp. and new records. Revista de Biología Marina, 28, 271-286.

Manter H.W., Van Cleave H.J. 1951. Some digenetic trematodes, including eight new species, from marine fishes of La Jollita, Calif. Proceedings of the United States National Museum, 101, 315-340.

Muñoz A.A., Ojeda F.P. 1998. Guild structure of carnivorous intertidal fishes of the Chilean coast: implications of ontogenetic dietary shifts. Oecologia, 114, 563-573. DOI: 10.1007/s11284004-0025-6.

Muñoz G., Olmos V. 2008. Revisión bibliográfica de especies endoparásitas y hospedadoras de sistemas acuáticos de Chile. Revista de Biología Marina y Oceanografia , 43, 173-245. DOI: 10.4067/S0718-19572008000200002.

Muñoz G., Zamora L. 2011. Ontogenetic variation in parasite infracommunities of the clingfish Sicyases sanguineus (Pisces: Gobiesocidae). Journal of Parasitology, (in press). DOI: 10.1645/GE-2445.1.

Oliva M.E., Ballón I. 2002. Metazoan parasites of the Chilean hake Merluccius gayi gayi as a tool for stock discrimination. Fisheries Research, 56, 313-320.
Oliva M.E., Luque J.L. 2002. Endohelminth parasites of the trambollo Labrisomus philippii (Steindachner) (Osteichthyes: Labrisomidae) from the central Peruvian Coast. Comparative Parasitology, 69, 100-104. DOI: 10.1654/1525-2647(2002) 069[0100:EPOTTL]2.0.C0;2.

Oliva M.E., Castro R.E., Burgos R. 1996. Parasites of the flatfish Paralichthys adspersus (Steindachner, 1867) (Pleuronectiformes) from Northern Chile. Memorias do Instituto Oswaldo Cruz, 91, 301-306.

Overstreet R.M., Curran S.S. 2002. Superfamily Bucephaloidea Poche 1907. In: (Eds. D.I. Gibson, A. Jones, and R.A. Bray) Keys to the Trematoda. Vol. 1, CABI Publishing and the Natural History Museum, Wallingford, 67-112.

Ozaki Y. 1928. Some gasterostomatous trematodes of Japan. Japanese Journal of Zoology, 2, 35-60.

Riggin G.T., Sparks A.K. 1962. A new gasterostome, Bucephaloides megacirrus from the redfish, Sciaenops ocellata. Proceedings of the Helminthological Society of Washington, 29, 27-29.

Salinas X., González M.T., Acuña E. 2008. Parasites of granadier Nezumia pulchella (Macrouridae) from southeastern Pacific coast of Chile and their use for discrimination of host populations. Journal of Fish Biology, 73, 683-691. DOI: 10.1111/ j.1095-8649.2008.01967.x

Sambrook J., Fritsch E.F., Maniatis T. 1989. Molecular cloning: a laboratorymanual. 2nd ed. Cold SpringHarbor, New York, Cold Spring Harbor Laboratory Press.

Yamaguti S. 1952. Parasitic worms mainly from Celebes. Part 1. New digenetic trematodes of fishes. Acta Medicinae Okayama, 8 , 146-198. 